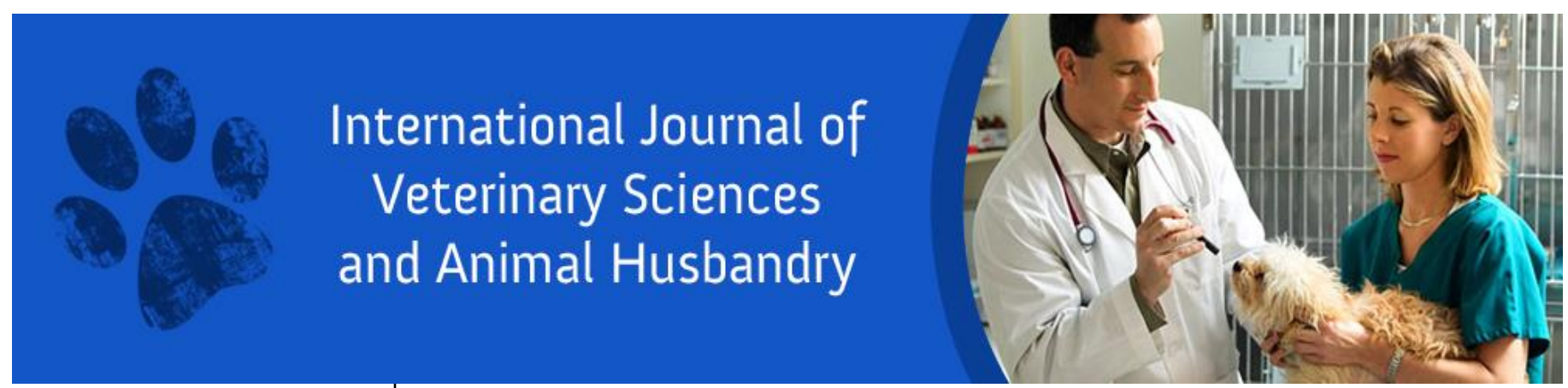

ISSN: $2456-2912$

VET 2021; 6(1): 28-30

(C) $2021 \mathrm{VET}$

www.veterinarypaper.com

Received: 19-11-2020

Accepted: 21-12-2020

\section{Lokendra Singh}

Department of Livestock

Products Technology, College of

Veterinary and Animal Science,

Navania, Vallabhnagar,

Udaipur, Rajasthan, India

Umesh S Suradkar

Department of Livestock

Products Technology, Post

Graduate Institute of Veterinary

Education and Research, Jaipur,

Rajasthan, India

\section{Dinesh M Chavhan}

Department of Livestock

Products Technology, College of

Veterinary and Animal Science,

Navania, Vallabhnagar,

Udaipur, Rajasthan, India

\section{Narendra Singh Rathore}

Department of Veterinary

Biochemistry, College of

Veterinary and Animal Science,

Bikaner, Rajasthan, India

\section{Karishma Rathore}

Department of Veterinary

Microbiology, College of

Veterinary and Animal Science,

Navania, Vallabhnagar,

Udaipur, Rajasthan, India

\section{Praveen Kumar}

Department of Livestock

Products Technology, College of

Veterinary and Animal Science,

Navania, Vallabhnagar,

Udaipur, Rajasthan, India

Ramesh Chand Jat

Department of Livestock

Products Technology, College of

Veterinary and Animal Science,

Navania, Vallabhnagar,

Udaipur, Rajasthan, India

\section{Corresponding Author:}

Lokendra Singh

Department of Livestock

Products Technology, College of

Veterinary and Animal Science,

Navania, Vallabhnagar,

Udaipur, Rajasthan, India

\title{
Study of the shelf life of goat milk paneer at refrigeration temperature
}

\section{Lokendra Singh, Umesh S Suradkar, Dinesh M Chavhan, Narendra Singh Rathore, Karishma Rathore, Praveen Kumar and Ramesh Chand Jat}

DOI: https://doi.org/10.22271/veterinary.2021.v6.i1a.322

\section{Abstract}

In the present study, goat milk is standardized on the level of 5 percent fat, was used in manufacturing of paneer using 0.10 percent calcium chloride as additive and 1 per cent citric acid solution as coagulant at $85^{\circ} \mathrm{C}$ coagulation temperature. $\mathrm{pH}$, titratable acidity and sensory evaluation were checked to know the shelf life of goat milk paneer during 12 days storage at $4 \pm 1{ }^{\circ} \mathrm{C}$. The mean value of titratable acidity and $\mathrm{pH}$ at refrigeration temperature $\left(4 \pm 1{ }^{\circ} \mathrm{C}\right)$ found to be increased significantly $(p<0.05)$ with increasing storage periods. A decreasing trend was recorded for scoring offered for all sensory parameters of a paneer at refrigeration temperature $\left(4 \pm 1^{\circ} \mathrm{C}\right)$ with the advancement of storage period. It was found that based on certain physico-chemical properties ( $\mathrm{pH}$ and acidity) and sensory evaluation, the shelf life of goat milk paneer at refrigeration temperature $\left(4 \pm 1^{\circ} \mathrm{C}\right)$ was 12 days.

Keywords: goat milk, paneer, refrigeration temperature, shelf life

\section{Introduction}

Livestock sector plays an important role in India economy. Goats are an important part of the livestock industry and play a crucial role in the socio-economic structure of marginal farmers in India. India possesses 148.88 million goats and is ranked second in the world in terms of the goat population (Basic Animal Husbandry Statistics, 2019) ${ }^{[5]}$. Total milk production in India is 187.75 million tone and goat milk contribution is 3 percent of total milk production in India (Basic Animal Husbandry Statistics, 2019) ${ }^{[5]}$.

In recent years goat milk and its product are receiving a real alteration in many countries of the world. Goat milk are useful for health of children especially who have allergy to cow milk (Playford et al., 2000) ${ }^{[10]}$. Goat milk can be used to prepare a wide variety of dairy products as paneer, cheese, butter, ice-cream, butter milk, condensed milk, yoghurt, flavoured milk, sweets and candy (Fazilah et al., 2018) ${ }^{[3]}$.

According to Chandan (2007) ${ }^{[2]}$ an estimate about 5 percent of milk produced in India is converted into paneer. Good quality paneer is characterized by a marble white color, sweetish, mildly acidic taste, nutty flavour, spongy body and closely knit smooth texture (Patel, 1991) [8]. High grade paneer has a pleasing, mild acidic, slightly sweet and nutty flavour, firm cohesive and spongy body and compact (close-knit), smooth and velvety texture (Patil and Gupta, 1986) ${ }^{[9]}$.

Paneer and chhana are the two important Indian traditional coagulated dairy product. Mostly small-scale traders and halwais produce these dairy products by traditional methods. The unhygienic condition maintained during manufacture lead to a lower shelf life of these products. The demand for these products is increasing every year. There is a great concern to produce new product development with high quality and high shelf life products that requires modern processing technology.

The present research work was carried out as an attempt to utilize goat milk for the preparation of paneer, a value added product by using modern processing technology and check the shelf life of paneer. 


\section{Materials and Methods}

\subsection{Preparation of paneer}

Fresh goat milk was procured from livestock research station, Bojunda, Chittorgarh and standardized to 5 percent fat in preparation of paneer. The product was prepared by the process suggested by Sachadeva and Singh (1988) ${ }^{[12]}$ with slight modification. The standardized goat milk was added with 0.10 percent calcium chloride and heated to $90{ }^{\circ} \mathrm{C}$ without holding then subsequently cooled to $85^{\circ} \mathrm{C}$ and at this temperature 1 percent citric acid solution as coagulant were added slowly with continuous agitation till clear whey separated out. The coagulum was left for 5-10 minutes in the whey and then it drained through muslin cloth and pressed in a hoof at 2-3 $\mathrm{kg} / \mathrm{cm}^{2}$ pressure. Paneer block was dipped in chilled water for 5-10 minute and packaged in pre-sterilized LDPE pouches and stored at $4 \pm 1{ }^{\circ} \mathrm{C}$.

\subsection{Analysis of the product}

Paneer was analyzed for $\mathrm{pH}$, acidity and sensory evaluation on $0,3^{\text {rd }}$ day, $6^{\text {th }}$ day, $9^{\text {th }}$ day and $12^{\text {th }}$ day of storage period at refrigeration temperature $4 \pm 1{ }^{\circ} \mathrm{C}$.

\subsection{1 pH}

Goat milk paneer were analyzed for $\mathrm{pH}$. The $\mathrm{pH}$ of the product was determined by the Potentiometric Method using a table top model of (SANCO, India). The method described by Franklin and Sharpe (1963) ${ }^{[4]}$ for cheese was used.

\subsubsection{Titrable acidity}

The titrable acidity of goat milk paneer was determined as per the method specified in IS 1479 (Part - 1) (1960) ${ }^{[7]}$.

\subsubsection{Sensory evaluation}

The goat milk paneer was subjected to the sensory evaluation by a panel of five judges from the Department of Livestock Products Technology and Department of Veterinary Public Health by using the procedure described in IS 6273 (Part II) (1971) ${ }^{[6]}$. The product was judged for different quality attributes by 9 point Hedonic scale (Amerine et al.,1967) ${ }^{[1]}$.

\subsection{Statistical analysis}

Data were statistically analyzed by using the method described by Snedecor and Cochran (1989) ${ }^{[13]}$.

\section{Results and Discussion}

\subsection{Changes in $\mathbf{p H}$ of paneer during storage}

The fresh and stored samples of paneer were analyzed for $\mathrm{pH}$. The data obtained for $\mathrm{pH}$ during storage at $4 \pm 1{ }^{\circ} \mathrm{C}$ are presented in Table 1 . The tabulated values show that the storage period has a significant $(p \leq 0.05)$ effect on $\mathrm{pH}$ of paneer at refrigeration temperature on $3^{\text {rd }}$ day of storage. The initial value of $5.89 \pm 0.01 \mathrm{pH}$ decreased significantly $(p \leq 0.05)$ to $5.88 \pm 0.02$ on $3^{\text {rd }}$ day, $5.79 \pm 0.01$ on the $9^{\text {th }}$ day and thereafter also it was having a decline. It reached to 5.68 $\pm 0.01 \mathrm{pH}$ on $12^{\text {th }}$ day of storage and was found unacceptable by the sensory panel of judges after 12 days which is delineated and discussed in section 3.3. The observed reduced $\mathrm{pH}$ value might be due to increase in acidity by lactose fermentation and/or microbial changes in the product during storage. Rai et al. (2008) ${ }^{[11]}$ also reported a similar declining trend for $\mathrm{pH}$ on storage of paneer for 15 days at $\left(4 \pm 1{ }^{\circ} \mathrm{C}\right)$.

\subsection{Changes in acidity of paneer during storage}

The fresh and stored samples of paneer were analyzed for acidity. The data obtained for acidity changes in paneer during storage at $4 \pm 1{ }^{\circ} \mathrm{C}$ are presented in Table 1 . The values in the table suggest that the storage period has significant $(p \leq 0.05)$ effect on acidity of paneer at refrigeration temperature. It is observed that there is a progressive increase in acidity of paneer. Fresh paneer had the acidity of $0.34 \pm 0.00$ per cent LA which increased significantly $(p \leq 0.05)$ to 0.39 \pm 0.00 on $3^{\text {rd }}$ day, $0.45 \pm 0.00$ on $6^{\text {th }}$ day, $0.48 \pm 0.02$ on $9^{\text {th }}$ day and $0.50 \pm 0.02$ per cent LA on $12^{\text {th }}$ day of storage at refrigeration temperature. Thus, the acidity of the paneer increased significantly $(\mathrm{p} \leq 0.05)$ at each period of storage studied. After 12 days of storage at refrigeration temperature the product was found unacceptable by the sensory panel of judges, which is delineated and discussed in section 3.3. The results obtained are in corroboration with those obtained by Rai et al. (2008) ${ }^{[11]}$ that the initial value for TA (\%LA) of paneer increased gradually from 0.31 to 0.59 during 15 days of shelf life study of paneer. Thus, it can be observed from the present study of storage of paneer at refrigeration temperature $\left(4 \pm 1{ }^{\circ} \mathrm{C}\right)$ that paneer prepared from goat milk can well be stored up to 12 days thereafter it becomes unacceptable with respect to its physicochemical ( $\mathrm{pH}$ and acidity) properties.

Table 1: Effect of storage period on the $\mathrm{pH}$ and acidity of paneer stored at refrigeration temperature $\left(4 \pm 1{ }^{\circ} \mathrm{C}\right)$

\begin{tabular}{|c|c|c|c|c|c|}
\hline \multirow{2}{*}{ Attributes } & \multicolumn{5}{|c|}{ Storage period (Days) } \\
\cline { 2 - 6 } & $\mathbf{0}$ & $\mathbf{3}$ & $\mathbf{6}$ & $\mathbf{9}$ & $\mathbf{1 2}$ \\
\hline $\mathrm{pH}$ & $5.89^{\mathrm{a}} \pm 0.02$ & $5.88^{\mathrm{b}} \pm 0.01$ & $5.87^{\mathrm{b}} \pm 0.00$ & $5.79^{\mathrm{c}} \pm 0.01$ & $5.68^{\mathrm{d}} \pm 0.01$ \\
\hline Acidity (\%LA) & $0.34^{\mathrm{e}} \pm 0.00$ & $0.39^{\mathrm{d}} \pm 0.00$ & $0.45^{\mathrm{c}} \pm 0.00$ & $0.48^{\mathrm{b}} \pm 0.02$ & $0.50^{\mathrm{a}} \pm 0.02$ \\
\hline
\end{tabular}

Each observation is a mean \pm SE of three replicate experiment $(n=3)$

Mean in row bearing a common superscripts do not differ significantly $(p<0.05)$.

\subsection{Changes in sensory attributes of paneer during storage}

The results obtained for changes in sensory attributes of fresh and stored samples of paneer are presented in Table 2. Fresh paneer had a general appearance score of $8.03 \pm 0.05$ which was found to decrease significantly $(p \leq 0.05)$ to $7.56 \pm 0.03$ on $3^{\text {rd }}$ day of storage. The general appearance scores till $9^{\text {th }}$ days of storage was statistically similar to $3^{\text {rd }}$ day than further decrease significantly $(p \leq 0.05)$ to $7.00 \pm 0.05$ on $12^{\text {th }}$ days of storage. However, the paneer was acceptable till $12^{\text {th }}$ days of storage with respect to general appearance.

It can be seen that storage period had a significant $(p \leq 0.05)$ effect on taste and flavour score of paneer. The taste and flavour score of paneer during storage tend to decrease with the increase in storage period. Paneer samples at $3^{\text {rd }}$ days were statistically at par with fresh samples. Fresh paneer had a taste and flavour score of $7.93 \pm 0.04$ which was found to decrease significantly $(p \leq 0.05)$ to $7.50 \pm 0.03$ on storage period of $6^{\text {th }}$ day, $7.40 \pm 0.05$ on $9^{\text {th }}$ day and it further decreased significantly $(p \leq 0.05)$ to $7.13 \pm 0.10$ on $12^{\text {th }}$ day of storage. The product was acceptable till 9 days of storage and at 12 days, the product was not acceptable due to development of bitter taste in the product.

It is evident from tabulated values that the paneer had an initial body and texture score of $8.10 \pm 0.03$ which decreased significantly $(p \leq 0.05)$ to $7.67 \pm 0.05$ on $3^{\text {rd }}$ day, $7.53 \pm 0.07$ on 
$9^{\text {th }}$ day and $7.13 \pm 0.10$ on $12^{\text {th }}$ day of refrigerated temperature storage. The body and texture of the product was even acceptable up to $12^{\text {th }}$ day of storage.

Fresh paneer had an overall acceptability score of $8.20 \pm 0.03$ which decreased significantly $(p \leq 0.05)$ to $7.93 \pm 0.04$ on $3^{\text {rd }}$ day, $7.5 \pm 0.03$ on 9 day and further it declined to $7.23 \pm 0.05$ on $12^{\text {th }}$ day of storage. However, the overall acceptability score of paneer at $3^{\text {rd }}$ and $6^{\text {th }}$ day of storage was found to be statistically similar. Thus, on the basis of sensory properties, it can be concluded that paneer can give a shelf life of 12 days under refrigeration temperature.

The results obtained are in agreement with those of Wadatkar et al. (2015) ${ }^{[14]}$. They observed that the score for flavor, colour and appearance, body and texture and overall acceptability declined as the period of storage elapsed.

Table 2: Effect of storage period on sensory quality of paneer stored at refrigeration temperature $\left(4 \pm 1{ }^{\circ} \mathrm{C}\right)$

\begin{tabular}{|c|c|c|c|c|c|}
\hline \multirow{2}{*}{ Sensory Attributes } & \multicolumn{5}{|c|}{ Storage period (Days) } \\
\cline { 2 - 6 } & $\mathbf{0}$ & $\mathbf{3}$ & $\mathbf{6}$ & $\mathbf{9}$ & $\mathbf{1 2}$ \\
\hline General Appearance & $8.03^{\mathrm{a}} \pm 0.05$ & $7.56^{\mathrm{b}} \pm 0.03$ & $7.50^{\mathrm{b}} \pm 0.03$ & $7.43^{\mathrm{b}} \pm 0.02$ & $7.00^{\mathrm{c}} \pm 0.05$ \\
\hline Taste and Flavour & $7.93^{\mathrm{a}} \pm 0.04$ & $7.80^{\mathrm{a}} \pm 0.03$ & $7.50^{\mathrm{b}} \pm 0.03$ & $7.40^{\mathrm{b}} \pm 0.05$ & $7.13^{\mathrm{c}} \pm 0.10$ \\
\hline Body and Texture & $8.10^{\mathrm{a}} \pm 0.03$ & $7.67^{\mathrm{b}} \pm 0.05$ & $7.63^{\mathrm{b}} \pm 0.05$ & $7.53^{\mathrm{c}} \pm 0.07$ & $7.10^{\mathrm{d}} \pm 0.04$ \\
\hline Overall Acceptability & $8.20^{\mathrm{a}} \pm 0.03$ & $7.93^{\mathrm{b}} \pm 0.04$ & $7.73^{\mathrm{b}} \pm 0.04$ & $7.50^{\mathrm{c}} \pm 0.03$ & $7.23^{\mathrm{d}} \pm 0.05$ \\
\hline
\end{tabular}

Each observation is a mean \pm SE of three replicate experiment $(n=3)$

Mean in row bearing a common superscript does not differ significantly $(p \leq 0$. 05).

\section{Conclusion}

Based on the results obtained in this study it can be concluded that paneer gave an acceptable product till the storage period of 12 days at refrigeration temperature $\left(4 \pm 1^{\circ} \mathrm{C}\right)$

\section{References}

1. Amerine MA, Pongborn RM, Roessler EM. A Principle of sensory evaluation of foods. Academic Press, New York 1967.

2. Chandan RC. Cheese varieties made by direct acidification of hot milk. In Hui YH (eds) Handbook of food products manufacturing Wiley-Inter Science, John Eiley and Sons Inc., Pub 2007; I:645-650.

3. Fazilah NF, Ariff AB, Khayat ME, Rios-solis, Halim M. Influence of probiotics, prebiotics, synbiotics and bioactive phytochemicals on the formulation of functional yoghurt. J of functional foods 2018;48:387399.

4. Franklin JG, Sharpe ME. The incidence of bacteria in cheese milk and Cheddar cheese and their association with flavour. J Dairy Res 1963;30(1):87-99.

5. http://www.dahd.nic.in. 17 Jun, 2019.

6. IS. Guide for sensory evaluation of foods Part II. Methods and evaluation cards. Indian Standards Institution, Manak Bhavan, New Delhi 6273, 1971.

7. IS. Methods of test for dairy industry Part I. Rapid examination of milk. Indian Standards Institution, Manak Bhavan, New Delhi 1479, 1960.

8. Patel RK. Indigenous milk products of India. Indian dairym 1991;43:120-125.

9. Patil GR, Gupta SK. Some aspects of sensory evaluation of paneer. Indian Dairyman 1986;38(3):135-140.

10. Playford RJ, Macdonald CE, Johnson WS. Colostrum and milk derived peptide growth factors for the treatment of gastrointestinal disorders. Am. J Clinical Nutrition 2000;72:5-14.

11. Rai S, Goyal GK, Rai GK. Effect of modified atmosphere packaging and storage on the chemical quality of paneer. J. Dairy, Food Home Sci 2008;27:33-37.

12. Sachdeva S, Singh S. Optimization of process in parameters in the manufacture of paneer. J Fd Sci Technol 1988;25(3):142-145.

13. Snedecor GW, Cochran WJ. Statistical methods, 8th ed. Lowa state university press, Amer, lowa, US 1989.

14. Wadatkar HV Shelke RR, Bhoyar D. Preparation of paneer from buffalo milk blended with soya milk. Journal of Agricultural Engineering and Food Technology 2015;2:68-69. 